\title{
31. REGIONAL ASPECTS OF DEEP SEA DRILLING IN THE NORTHEAST PACIFIC
}

\author{
Dean A. McManus, University of Washington, Seattle, Washington \\ Oscar Weser, Chevron Oil Field Research Company, La Habra, California \\ C. C. von der Borch, Scripps Institution of Oceanography, La Jolla, California \\ Tracy Vallier, Indiana State University, Terre Haute, Indiana \\ Robert E. Burns, ESSA - University of Washington, Seattle, Washington
}

\section{INTRODUCTION}

Many aspects of the drilling results from Leg 5 are of a regional nature that merit at least a general presentation in this report. These aspects include the rates of sedimentation, the physical stratigraphy, gross relationships with nearby sections on land and information bearing on the sea floor spreading hypothesis.

\section{SEDIMENTATION RATES}

On Tables 1 and 2 are listed the sedimentation rates of the various time-rock units encountered at Holes 32 through 42. No entries were made for Hole 43 , as it lacked the paleontological data with which to define time boundaries. The boundaries of the time-rock units are based on paleontological criteria used by the Deep Sea Drilling Project. The absolute ages assigned to the time-units were derived from the correlation chart constructed by Berggren (1969). These ages are based on radiometric age-datings. It is obvious that even small errors in the absolute scale will affect the sedimentation rate values. These effects can be particularly significant for those time-rock intervals of short-time duration, and the results on Tables 1 and 2 should be evaluated accordingly.

Calculations of sedimentation rates are based on in situ thicknesses at the drill sites, and no attempt has been made to correct for sediment compaction.

All sediment intervals have moderate to high interstitial water contents. At the terrigenous sites this content varies between 45 to 65 per cent, except for Hole 35 where it averages 30 per cent. The water content of the pelagic sediments ranges from 50 to 90 per cent. One must compensate accordingly for this high water content, when comparing the sedimentation rates presented here with rates given for compacted sediments.

On Table 1, ail sedimentation rates are rounded off to the nearest meter since most rates are quite high and the quality of the data does not warrant further refinement. However, on Table 2 the values of many of the depositional rates are less than or slightly more than $1 \mathrm{~m} / \mathrm{m} . \mathrm{y}$; here, all rates are calculated one place beyond the decimal point (that is, to the nearest 100,000 years).
An examination of the two correlation charts (Figures 2 and 3) indicates that many of the Epoch and subEpoch boundaries occur between cored intervals. This introduces a plus or minus value to many of the sedimentation rates. Other factors which are involved in the validation of many of these rates, plus, the significance of some of the depositional rates, will be outlined for each hole in the following section.

\section{Site 32}

In the Lower Pliocene interval there is a hiatus of about 1.25 million years. The calculated sedimentation rate of $26 \mathrm{~m} / \mathrm{m} . \mathrm{y}$. shown for this interval on Table 1 reflects this hiatus. Lower in the hole, the Early Miocene-Late Oligocene boundary could not be recognized; consequently, a sedimentation rate for the combined interval was calculated.

Table 1 shows that the Early Pliocene and younger intervals had a moderately high sedimentation rate ( 25 to $32 \mathrm{~m} / \mathrm{m} . \mathrm{y}$.). This rate shows a progressive decrease as the sediments become older, and reflects a change from terrigenous to pelagic deposition. It is further influenced by a continuous decrease in the siliceous fossil content of the older sediments.

\section{Sites 33 and 34}

At Site 34 a problem arose in determining a depositional rate for the pre-Middle Miocene sediments. A disagreement exists as to the age of the oldest sediments (which occur in Core 17). A 23.5 to 27.0-million year age is indicated on the basis of calcareous nannofossils and a 32 to 36 -million year age is suggested by the foraminifera. At present an age closer to $23.5 \mathrm{mil}$ lion years appears to be more reasonable. On this basis a sedimentation rate of $3 \mathrm{~m} / \mathrm{m} . y$. (actually $3.5 \mathrm{~m} / \mathrm{m} . \mathrm{y}$.) can be established for the Early Miocene/Late Oligocene (undifferentiated) strata.

If one were to use the minimum foraminiferal age ( 32 million years) for the oldest datable sediments, a sedimentation rate of $2 \mathrm{~m} / \mathrm{m} . \mathrm{y}$. would be established for these strata. Using this rate to interpolate the thirty meters of undated sediments above basement would result in a 47-million year age at total depth. 
TABLE 1

Depositional Rates at Holes 32 through 36. Rates in Meters/Million Years.

\begin{tabular}{|l|c|c|c|c|c|c|}
\hline $\begin{array}{l}\text { Epochs and } \\
\text { Sub-Epochs }\end{array}$ & $\begin{array}{c}\text { Absolute Age } \\
\text { (million years) }\end{array}$ & 32 & 33 & 34 & 35 & 36 \\
\hline Pleistocene & $0.0-2.0$ & 25 & 29 & 20 & 560 & 24 \\
Late Pliocene & $2.00-3.25$ & 32 & 38 & 37 & & 15 \\
Early Pliocene & $3.25-5.50$ & 26 & 20 & 24 & & 16 \\
Late Miocene & $5.5-11.5$ & 10 & 16 & 19 & & 2 \\
Middle Miocene & $11.5-14.0$ & 4 & 24 & 25 & & 3 \\
Other & & $2^{\mathrm{a}}$ & & $2-3^{\mathrm{b}}$ & & \\
\hline
\end{tabular}

${ }_{\mathrm{b}}^{\mathrm{a}}$ Early Miocene/Lower Oligocene undifferentiated.

$\mathrm{b}$ Early Miocene/Lower Oligocene-Early Oligocene?

TABLE 2

Depositional Rates at Holes 37 through 42. Rates in Meters/Million Years.

\begin{tabular}{|l|c|c|c|c|c|c|c|}
\hline $\begin{array}{l}\text { Epochs and } \\
\text { Sub-Epochs }\end{array}$ & $\begin{array}{c}\text { Absolute Age } \\
\text { (million years) }\end{array}$ & 37 & \multicolumn{5}{|c|}{ Holes } \\
\hline Pleistocene & $0.0-2.0$ & 1.5 & 5.5 & $1.5-3.5$ & & & \\
Early Oligocene & $31.7-36.0$ & & & & & & 2.3 \\
Late Eocene & $36.0-45.0$ & & & & & 2.2 & 3.0 \\
Middle Eocene & $45.0-49.0$ & & & & & $2.0-8.0$ & 12.9 \\
Early Eocene & $49.0-53.5$ & & 6.0 & & & & \\
Other & & $0.8^{\mathrm{a}}$ & $0.6^{\mathrm{b}}$ & $0.3^{\mathrm{b}}$ & $18.5^{\mathrm{c}}$ & & \\
\hline
\end{tabular}

${ }^{\text {a }}$ Pliocene/Lower Oligocene.

$\mathrm{b}_{\text {Pliocene/within Early Eocene. }}$

${ }^{c}$ Middle Eocene/Early Eocene.

At Sites 33 and 34, where no pelagic sediments were seen in the cored intervals, all Middle Miocene and younger intervals had moderate sedimentation rates. Only the older zeolitic sediments in Cores 14 through 17 had a depositional rate $(3 \mathrm{~m} / \mathrm{m} . \mathrm{y}$.) similar to that of pelagic deposits.

\section{Site 35}

The Pleistocene fossils encountered at Site 35 do not indicate which portion of this Epoch they represent. However, the location of this site over the Gorda Rise suggests the sediments are no older than 700,000 years (i.e., Brunhes Normal). On this basis a sedimentation rate of $560 \mathrm{~m} / \mathrm{m}$.y. should be considered as a minimum value.
Site 36

The sedimentation rates established at this site are fairly reliable, because all paleontological boundaries are within cored intervals. A recognizable time-gap of 2.0 million years occurs between the younger terrigenous and the older pelagic sediments in Core 12, Section 6. This time-gap was taken into account in calculating the sedimentation rate of the Middle Miocene sediments.

At this site, where nannofossil ooze is the dominant facies, only the sedimentation rate of the Pleistocene interval $(24 \mathrm{~m} / \mathrm{m} . \mathrm{y}$.) is comparable to that of the same intervals at Sites 32, 33 and 34 ( 20 to $29 \mathrm{~m} / \mathrm{m} . \mathrm{y}$.). All of the older intervals have slower rates than those of 
equivalent strata at these two sites. The rate of $3 \mathrm{~m} / \mathrm{m} . \mathrm{y}$. for the pelagic Middle Miocene interval is somewhat higher than that normally associated with pelagic sedimentation in the Pacific Ocean. More difficult to explain is the $2 \mathrm{~m} / \mathrm{m}$.y. sedimentation rate for the overlying terrigenous Upper Miocene interval. Perhaps depositional gaps other than the one at the base of this interval are present and have not been recognized.

\section{Site 37}

Many assumptions were involved in defining a Pleistocene sedimentation rate at this site. Found here is an interval of light-brown "red" clay, containing Pleistocene fossils, which represents an unknown portion of this Epoch. This "red"-clay facies, which is believed to represent a period of more intensive Pleistocene glacialeolian activity, actually extends down to an in-hole depth of 5 meters. However, the lower two meters of this unit are assumed to represent coring duplication. Consequently, only 3 meters of glacial Pleistocene sediments are probably present. The beginning of this coldwater period, no doubt, is younger than the 2.0 million years commonly assigned to the Plio-Pleistocene boundary. However, because a more accurate date is not available, the 2.0-million year figure is used for the calculations made here.

Below the 5-meter interval, there are 25 meters of nonfossiliferous sediments. All that can be assumed on the basis of drilling Site 37 at Magnetic Anomaly 10 is that deposition began approximately 32 million years ago; unconformities may or may not be present. On the basis of progressive changes in color, zeolite and amorphous iron-oxide content, one might assume that unconformities are absent. Then, if deposition proceeded uniformly, a sedimentation rate of $0.8 \mathrm{~m} / \mathrm{m} . \mathrm{y}$. is derived. Very likely the latter assumption is not correct. First, the proportion of detrital constituents shows a progressive uphole increase. Secondly, the amorphous iron-oxide sediments in the lower part of the hole may represent a more rapidly accumulating facies. Consequently, even if time-gaps are absent from the Site 37 sedimentation record, the average sedimentation rate of $0.8 \mathrm{~m} / \mathrm{m} . y$. for the pre-Pleistocene "red" clays might show significant individual variations.

\section{Site 38}

Many of the same problems of establishing sedimentation rates encountered at Site $\mathbf{3 7}$ are encountered at Site 38. The latter site, however, has a basal fossiliferous interval encompassing part of early Eocene time (i.e., 49.0 to 50.5 million years) for which a sedimentation rate of $6.0 \mathrm{~m} / \mathrm{m}$.y. can be assigned.

At the surface there is an 11-meter interval of lightbrown "red" clay which, although lacking in fossils, is considered to be the glacial Pleistocene interval (see
Chapter 30). The sedimentation rate of this inverval would be $5.5 \mathrm{~m} / \mathrm{m} . \mathrm{y}$.

Between these two intervals, there is a 28 -meter interval of "red" clay representing about 47 million years. Again assuming no unconformities and uniform deposition, a sedimentation rate of $0.6 \mathrm{~m} / \mathrm{m} . y$. is obtained. This rate is commensurate with those given by others for older "red" clays in the Pacific Ocean (see Chapter $30)$.

\section{Site 39}

The lithology and age-dating problems at Site 39 are similar to those found at Site 38. The former has a basal fossiliferous unit which is too thin to assign a sedimentation rate, but can be used to date the bottommost sediments as being 52 million years old.

Although only 3 meters of light-brown "red" clay of presumed glacial Pleistocene age were cored, an additional 4 meters of this sediment were possibly missed during coring operations (see Chapter 9). This accounts for the 1.5 to $3.5 \mathrm{~m} / \mathrm{m}$.y. sedimentation rate assigned to this interval on Table 2.

The intervening 14 meters of "red" clay represent 50 million years of time, which amounts to a sedimentation rate of $0.3 \mathrm{~m} / \mathrm{m} . \mathrm{y}$. This is the lowest rate for any Leg 5 interval, and lower than the minimum values mentioned in Chapter 30. It is not unreasonable, therefore, to postulate the presence of one or more depositional gaps in this "red" clay interval.

\section{Site $\mathbf{4 0}$}

At this site, sedimentation rates were only calculated for the Eocene radiolarian oozes. Because it was difficult to assign an absolute age to the Middle-Early Eocene boundary, a sedimentation rate was calculated for the combined intervals. The resulting $18.5 \mathrm{~m} / \mathrm{m} . \mathrm{y}$. rate is the highest for any of the pelagic sediments.

\section{Site 41}

The upper 6 meters at Site 41 are "red" clays which contain some radiolarians. Most are reworked Eocene forms; however, at 5 meters a few upper Miocene and younger forms were recognized. The top of the Upper Eocene is at about 6 meters. Thus, there is an hiatus involving some portion of Late Miocene or later time to Late Eocene time in the vicinity of 6 meters. Poor fossil data within this 6-meter interval precludes determining any sedimentation rates.

Below 6 meters there are more abundant fossils, and a sedimentation rate of $2.2 \mathrm{~m} / \mathrm{m}$.y. can be calculated for the Upper Eocene interval. There is some question as to the amount of absolute time represented by the 8-meter 
Middle Eocene interval at this site (that is, it could be anywhere from 1.0 to 4.0 million years). This accounts for the 2.0 to $8.0 \mathrm{~m} / \mathrm{m}$.y. range in sedimentation rate shown in Table 2.

\section{Site 42}

Few problems were encountered in age-dating the fossil oozes at this site, and fairly reliable sedimentation rates were obtained. These indicate progressively higher rates from Early Oligocene through Middle Eocene time. This behavior is believed to reflect higher productivity during earlier Cenozoic intervals.

There may be a slight hiatus between the Early Oligocene/Late Eocene; since its extent and duration, if present, are difficult to define, it was not recognized for purposes of calculating the sedimentation rates of the early Oligocene and Late Eocene intervals.

\section{PHYSICAL STRATIGRAPHY}

\section{Sites 32 through 36}

Sites 32 through 36 can be grouped together as the drilling sites near the continent of North America (Figure 1). As a result of their location, the physical stratigraphy for these sites was strongly influenced by terrigenous sedimentation. The major lithologic facies are presented in Figure 2 which, in a general sense, is a north-south section across the fracture zones transecting this part of the Pacific Ocean. Although most of the sites will be referred to as typifying an area or block on one side or the other of a fracture zone, the extent to which a site represents the sediment history of such a large area is unknown. This qualification is intended, if not stated, for each discussion of a facies that follows.

South of the Pioneer Fracture Zone, at Site 32, the lowermost facies is a "red" clay that overlies the basalt. Between the "red" clay and basalt is a thin dolomitic clay that may represent sediment altered by intrusion of the basalt. The "red" clay facies, which contains zeolites in the middle part of the unit, extends from Lower Oligocene through Middle Miocene. Between the Pioneer and Mendocino Fracture Zones, Sites 33 and 34 , sediments of this age are represented by different facies. Although the basal part of the sediment sequence at Site 33 was not cored, the nearness of Sites 33 and 34 suggests that the basal facies at Site 33 may be very similar to that at Site 34 , which is a mud. Zeolites are present in the middle part of this facies. On the basis of the sampled part of the section, therefore, sediments representing the period from the beginning of sedimentation to the beginning of the Middle Miocene are represented by "red" clay facies to the south of the Pioneer and a green mud facies to the north. Similarities between the facies include the fine-grained material, comparable sedimentation rates of 2 to $3 \mathrm{~m} / \mathrm{m}$.y., and the presence of zeolites. The differences, however, extend beyond color to include mineralogy. The "red" clay facies contains potassium feldspar, kaolinite, well-crystallized chlorite and other components in the fine-grained sediment (Rex, this volume) that are not present in the green mud facies. In addition, the "red" clay facies also contains thin, ash-like beds of angular, fragmented, unaltered feldspars and altered feldspar (?) grains; there is little quartz in either the coarse or fine material.

Either the two facies represent different conditions of sedimentation north and south of the Pioneer that resulted in comparable sedimentation rates, or else the originally similar material was subsequently altered at the site south of the Pioneer. The configuration of the sea floor between the sites at the time of sedimentation is unknown, but at present the sea floor at Site 32 is approximately 400 meters deeper than it is at Site 34 . The basalt at Site 32 is only 367 meters deeper than at Site 34. Such depth differences may or may not have been sufficient to influence bottom-seeking sedimentary processes. Another difference in the site locations is that Site 32 is situated at the end of an offset in the magnetic anomaly pattern suggesting that a fracture zone, though not detected in the topography, may be present at the site. The cause of the facies difference, however, remains unresolved.

At approximately the beginning of the Middle Miocene, the sediment north of the Pioneer Fracture Zone becomes a siliceous fossil-mud facies that continues up into the Early Pliocene. Within the Middle Miocene are layers of cherty mudstone that represent the only silicified units of Neogene age encountered on Leg 5 . (The cherts at Sites 40 and 42 at lower latitudes are of Eocene age.) Also in the Middle Miocene at Site 34, there are some thin nannofossil oozes.

Although the siliceous fossil-mud facies begins with the Middle Miocene north of the Pioneer, south of the fracture zone the "red" clay facies continues through the Middle Miocene.

Because the only Middle Miocene facies change which occurs near the Pioneer Fracture Zone is the introduction of planktonic fossil remains north of the Pioneer, the fracture zone itself cannot be considered as influencing a change in sedimentation. Productivity may have increased in the north because of changes in the physical-chemical regimen of the surface waters.

At Site 36, north of the Mendocino Fracture Zone, the lowermost facies is a thin Middle Miocene siliceousfossil "red" clay that passes upward into a "red" clay facies, also of Middle Miocene age. The sedimentation rate for these facies is comparable to that for the "red" 


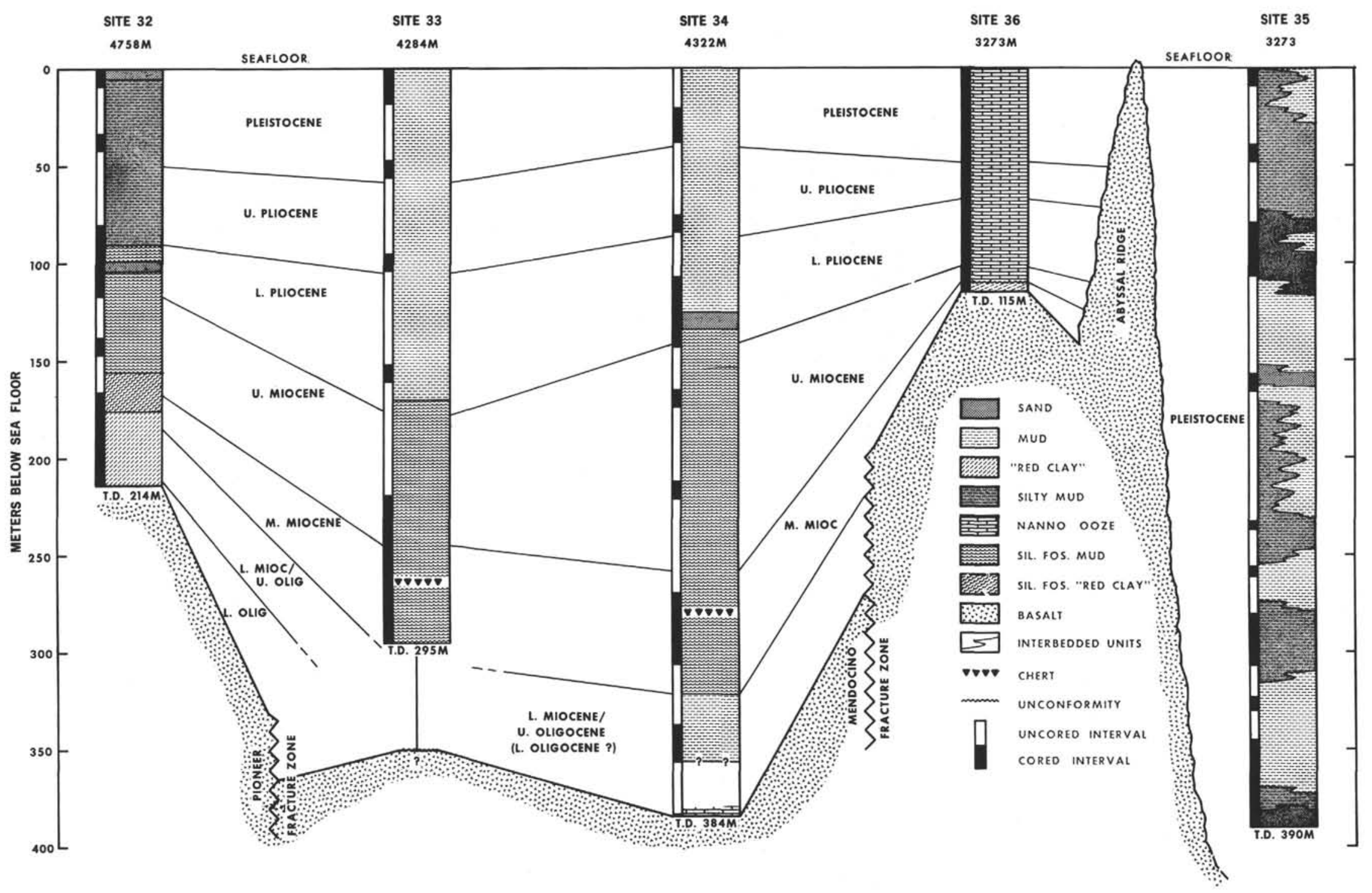

论 Figure 2. Correlation chart, Sites 32 through 36. 
clay at Site 32. Consequently, for the Middle Miocene a "red" clay facies is present north of the Mendocino and south of the Pioneer Fracture Zones, but siliceous fossils and green mud form the facies in-between. How representative each site is of sedimentation conditions in the areas between the separate fracture zones is unknown. The greater variability in facies across adjacent fracture zones than between more widely separated fracture zones suggests that radically different conditions existed, even with regard to the accumulation of planktonic remains on the sea floor.

Beginning in the Upper Miocene, the sediment facies south of the Pioneer becomes a siliceous-fossil "red" clay. Later within the Upper Miocene this facies changes again by the disappearance of the "red" clay with the sediment becoming a siliceous fossil-mud facies. For the first time since the beginning of sedimentation, similar facies occur north and south of the Pioneer Fracture Zone.

North of the Mendocino, the lower part of the Upper Miocene is missing. During the period of this hiatus, the siliceous fossil-mud facies is present between the Mendocino and Pioneer Fracture Zones, and the siliceous-fossil "red" clay facies is present south of the Pioneer. With the return of sedimentation in the upper part of the Upper Miocene at Site 36, a nannofossilooze facies with green mud is developed. Although at Sites 33 and 34 the siliceous fossil-mud facies continues during this period, at Site 32 this time interval approximates the beginning of the siliceous fossil-mud facies.

At Site 36 the nannofossil-ooze facies, with thin intervals of green mud, continues through the Pliocene and Pleistocene.

During latest Pleistocene time, a terrigenous sand and silty mud facies develops at Site 35 . This facies, largely representing turbidite deposition, contrasts with the nannofossil oozes depositing at the same time in the same block at Site 36 .

At Sites 32 and 34, the siliceous fossil-mud facies extends up into the Lower Pliocene, where a facies change occurs. This relationship is probably also true at Site 33, although sediments representing this interval were not cored. At Sites 33 and 34 a green mud facies is present. Some Lower Pliocene sands appear at Site 34, which is located at the distal end of the Delgada Fan. The Upper Pliocene part of this facies is poorly sampled, but some nannofossil oozes occur at Site 34, suggesting some facies continuity with similar oozes at Site 36.

The upper limit of the siliceous fossil-mud facies at Site 32 is uncertain because of the influx of sand and the reworked nature of some of the fossils. Either the facies extends to the Lower Upper Pliocene or stops in the Lower Pliocene. Within the Lower Pliocene there is also an interval of turbidite sand deposition which was shortly followed by the formation of an unconformity. The Upper Pliocene and Pleistocene at Site 32 are poorly sampled, but appear to be represented by a silty mud facies and a few sands.

In summary, it is possible to say that until upper Upper Miocene time the facies are different at the sites on each crustal block bounded by a fracture zone. Through the Middle Miocene, "red" clay facies represent this earlier period on what are now the shallowest and deepest blocks, that is, the northern and southern blocks. During the lower part of the Upper Miocene, an hiatus occurs at Site 36 but the "red" clay deposition continues on the southern block as a siliceous-fossil "red" clay. On the central block a green mud and siliceous fossil-mud facies develops. In the upper part of the Upper Miocene, the siliceous fossil-mud facies spreads to the central block as well. To the north, reflecting the spread of high biogenous productivity (or fossil preservation), the facies is represented by a nannofossil ooze along with some green mud, indicating, as at Site 32, the disappearance of conditions favorable for the formation of pelagic "red" clays.

North of the Mendocino Fracture Zone at Site 36, the nannofossil-ooze facies persists through the Pleistocene, as sedimentation conditions apparently changed little at this site during this period. In the Lower Pliocene on the crustal and southern blocks, the progradation of the Delgada Fan had extended sufficiently far from the continent to permit the introduction of coarser terrigenous sediment. The Pliocene-Pleistocene sections on the abyssal plains at Sites 32 and 34 reflect the mud and silty mud facies of the continuing terrigenous influence, as does the abyssal hill section at Site 33 .

During latest Pleistocene time, Site 36 no longer typified the northern block as mostly turbidites began accumulating at Site 35 .

\section{Sites $\mathbf{3 7}$ through $\mathbf{4 2}$}

The physical stratigraphy of Sites 37 through 42 (see Figure 3) is best discussed in two sections; these are as follows: (1) Sites 37, 38 and 39, and (2) Sites 40, 41 and 42. Sediments of the first group of sites are characteristically low in biogenous material and high in amorphous iron-oxide content (thought to be precipitated from hydrothermal exhalations, see Chapter 26). The second group of sites are dominated by biogenous sediments due to the proximity of the equatorial zone of high productivity. The above sites are discussed in turn below.

\section{Sites 37,38 and 39}

Details of the lithology of these three sites are given in Chapter 30. Due to the sparse occurrences of fossils, time boundaries between these sites cannot be shown. 


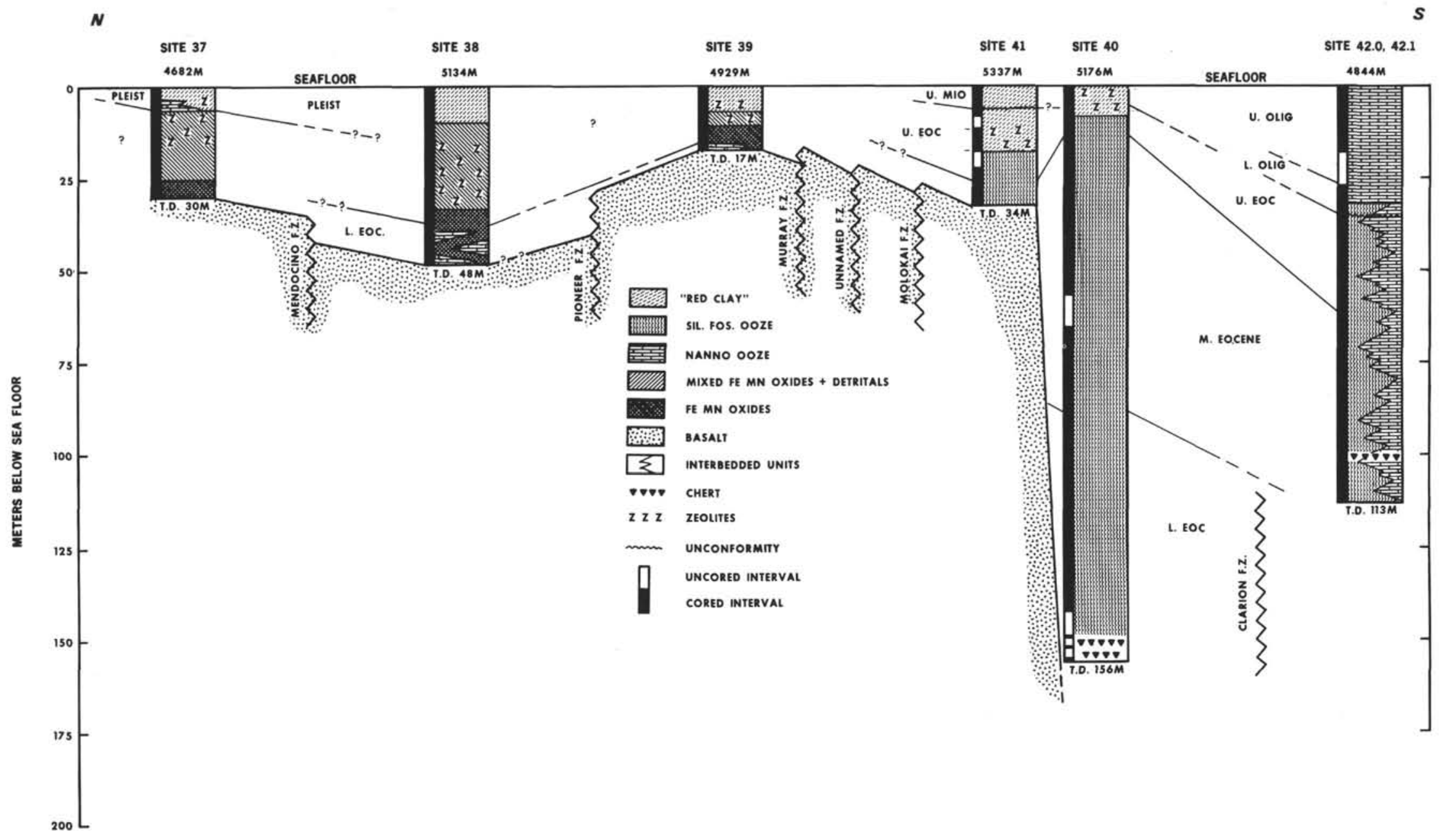

Figure 3. Correlation chart, Sites 37 through 42. 
All that can be stated is that the uppermost 6 meters of Site 37 are of Pleistocene age. Sites 38 and 39 both have occurrences of somewhat calcified calcareous nannoplankton within their basal sections, admixed with amorphous iron oxides. In both cases the nannoplankton are of Early Eocene age, suggesting a general correlation between at least two of the basal iron-oxide zones.

Although separated by the Mendocino and Pioneer Fracture Zones, correlative lithofacies can be recognized at these three sites (Chapter 26). At the bottom of all three holes is a basal amorphous iron oxide facies. This overlies basalt at Sites 37 and 39 and possible basalt at Site 38. This basal facies is overlain in all three cases by a mixed amorphous iron oxide and detrital facies which is in turn overlain by a so-called detrital facies. This uppermost facies falls within the broad category embraced by the term "deep-sea red clays".

A pronounced zeolitic unit, typified by aggregations and layers of phillipsite within otherwise pelagic clayey sediments, is present at all three sites-approximately in the middle section of each hole. As will be discussed in more detail below, similar phillipsite-rich zones occur within brown clays of Late Eocene age at Sites 40 and 41. These zones may be more or less contemporaneous.

\section{Sites $\mathbf{4 0 , 4 1}$ and $\mathbf{4 2}$}

Sites 40 and 41 are situated within 15 kilometers of one another. Site 40 , the shallower of the two, is in a zone of ponded sediment at the base of a large abyssal hill. Site 41 , considered the more regionally representative, is on the upper flank of a nearby abyssal hill. Site 42 and, to a certain extent, Sites 40 and 41 represent the northern limit of the equatorial belt of high productivity.

Of these three sites, the oldest sediment occurs at the base of the hole at Site 40 , which bottomed in Lower Eocene chert beds. Above these cherts, the Lower Eocene section is composed entirely of radiolarian oozes. Above these sediments are similar siliceous oozes of Middle Eocene age which correlate with comparable sediments overlying basalt at Site 41 . Further south at Site 42, the Middle Eocene sediments are composed entirely of various admixtures of calcareous and siliceous biogenous oozes. The presence of calcareous sediment at Site 42 may reflect its shallow depth, or it could be a function of locally higher productivity at that time, which resulted in rapid biogenic sedimentation.

The Upper Eocene time-rock unit is the only complete unit that can be carried between any of the sites in this north-south section. However, it can only be extended between Sites 41 and 42 . At Site 40, brown clays of unknown age appear to crop out on the sea floor. Sedi- ments of a roughly comparable age at Sites 40 and 41 are lithologically similar, and consist of phillipsitic brown clays overlying radiolarian oozes. To the south, as typified by Site 42 , time-equivalent sediments have varying admixtures of calcareous and siliceous biogenous oozes. This reflects, once again, the possibility of a higher productivity to the south, or it could be related to the shallower depth of Site 42.

The phillipsite-rich zone which occurs above the Upper Eocene sediments at Sites 40 and 41 may be partially time-equivalent to similar zones described previously at Sites 37, 38 and 39. If this is the case and on the assumption that the phillipsite results from the breakdown of volcanic components, then the phillipsite zone may be at least partly synchronous in the area embraced by Sites 37 to 41 . Subsequent radiometric dating will be required to validate this point.

The differing ages of the uppermost sediments of Sites 40,41 and 42 have no apparent pattern. The surface and nearsurface sediments at Site 40 are of unknown age. At Site 41, they are Late Miocene or younger and at Site 42 they are Late Oligocene. Sediments of Oligocene age were not recognized at Site 41 .

The uppermost interval of Site 42 is a relatively pure calcareous nannoplankton ooze of Late Oligocene age. It may be indicative of a period of high productivity near Site 42 during Oligocene times, related to the proximity of the equatorial divergence. The fact that surface sediments at this site are of Late Oligocene age suggests that, unless erosion has taken place, high productivity ceased in this area approximately at the close of the Oligocene. Subsequent more slowly deposited "red" clays could easily have been removed by bottom current activity or slumping either of which could account for their absence.

\section{MAGNETIC ANOMALY AND PALEONTOLOGICAL AGES}

\section{Introduction}

One of the original objectives for the proposed drilling sites on Leg 5 was the comparison of the paleontological age of the basal sediment in the stratigraphic section at the drilling site with the age of the underlying basalt as inferred from the magnetic anomaly age-dating system of Pitman and Heirtzler (1966), Vine (1966), and others.

Figure 4 compares the ages determined by these two methods for those sites at which basement was reached. At Sites 33, 40 and 42 drilling was terminated by chert. At Site 35 the nature of the sediment and deteriorating weather conditions caused the discontinuation of drilling. The basal sediment at Sites 37 and 43 was nonfossiliferous. 
If the sedimentation began on the basalt soon after its extrusion at the ridge crest, then the points in Figure 4 would lie along the $45^{\circ}$ line. Points below the line indicate sediment ages younger than the basement, and the distance from the line would represent the duration of the hiatus prior to the beginning of sedimentation. Points above the line represent sites with sediment older than the basalt, suggesting either incorrectly dated sediment or magnetic anomaly, or an abnormal condition.

\section{Site 36}

Site 36 is the youngest site for which the comparison can be made; and, it is also the one site for which the oldest sediment (13 million years) overlying the basalt is definitely older than the magnetic anomaly age $(<8$ million years). As this site is located just off the edge of the Raff and Mason (1961) magnetic survey, the location of the site with respect to the magnetic anomaly identification is precise. The paleontological control on the age-dating is very good, and the sediment age assignment seems reliable. Either the magnetic anomaly time-scale for this part of the anomaly age system is in error or else the anomaly at Site 36 has been misidentified by previous workers.

Support for a change in the magnetic time scale comes from the drilling results of Leg 3. One of the sites, Site 16, on the Mid-Atlantic Ridge was in material of comparable age in which the sediment-11 million years-was older than the magnetic anomaly-9 million years-(Maxwell et al., 1970). Consequently, the timescale in the Upper Miocene may be less certain than previously thought.

On the other hand, the identification of the magnetic anomaly at Site 36 may be in error. If the anomaly is actually 13 million years, then either the spreading rate was extremely slow during the more recent spreading time or else some anomalies are missing. The latter seems impossible because any surface flows of younger basalt would not be sufficiently thick to counteract the deep-seated source of the magnetic anomaly. The identification, therefore, would appear to be correct, giving further support to the error existing in the time scale itself.

There are certain characteristics of the sediment section at Site 36 that are related to topographic changes on the sea floor. In the Middle Miocene, the "red" clay facies with a moderately high barium content represents a distinct sedimentary environment on the ocean floor. Then, approximately 9 million years ago-after a 2 million year gap in the sediment record, the sedimentary environment was considerably altered, resulting in the commencement of terrigenous sedimentation. The presence of this sediment, plus the occurrence of Eocene and younger reworked fossils, connotes significant changes in the configuration of the sea floor and in the bottom currents. At this same time a major change in the sediment facies also occurred at Site 32. Therefore, it appears that approximately 9 million years ago a major change in sea-floor spreading direction or rate, or increased movement along the fracture zones, is recorded in the sediment history.

\section{Site 34}

At Site 34 the interpreted age of the oldest sediment differs depending upon whether calcareous nannoplankton or foraminifera are used. In addition the basal 28 meters of the sediment section were not cored. The combination of these two problems makes the predicted age of the basal sediment uncertain. However, as discussed in the section in this chapter on sedimentation rates, the assignment of the youngest end of the range shown on Figure 4 to the sample 30 meters above the basalt results in an extrapolated age of the basal sediment of 31.5 million years. Even though the basalt may be an intrusion, there does not appear to be a gross discrepancy in the ages assigned by the two methods.

With regard to the basalt as a possible intrusion, the alteration of the basalt should be kept in mind. The basalt is fractured, and the fractures are filled with calcite and chlorite. The regional significance of this alteration is unclear and, indeed, it may be a local effect. The site, however, is aligned with the Gorda Ridge, north of the Mendocino Fracture Zone where a new northeast-trending spreading center developed subsequent to the time of emplacement of the basalt at Site 34. There may or may not be an association of the new spreading center being located on one plate and the basalt being altered on the adjacent plate at a point along the trend of the spreading center.

\section{Site 32}

Site 32 also has basal sediment suggestive of having been intruded, although the basalt is not altered as at Site 34. An intrusive contact could contribute to the discrepancy in ages assigned by the two methods.

\section{Sites 38 and 39}

At Sites 38 and 39 the sediment is younger than the basalt by 6 to 8 million years. The presence of the amorphous iron-oxide facies in the lower sediments at these sites suggests that sediment accumulation began very near the ridge crest. Therefore, a hiatus would not be expected between the sediments and the basalt; and, it would not account for the younger age of the sediment. Instead, it might be thought that the charting of the magnetic anomalies in this part of the Pacific was not sufficiently accurate for the resolution required here. This explanation would suggest errors in locating the magnetic anomalies of almost 170 nautical miles, 
however, which seems excessive. Rather, it would appear that fracture zones or other disruptions of the magnetic anomaly pattern have not been fully evaluated yet for their effect in this part of the region. The other possibility is that the extrapolated ages assigned to the magnetic anomalies need revision.

\section{Sites $\mathbf{4 0}$ and $\mathbf{4 1}$}

The age of the basal sediment at Site 41 is based upon the radiolarians which have been matched with Berggren's (1969) chart. The paleontological age, therefore, would reasonably appear to be within the range shown in Figure 4. The discrepancy in ages determined by the two methods is excessive. In addition to the anomalously young sediment age at the base of Site 41, there are other peculiar characteristics associated with Sites 40 and 41 which bear upon this problem.

The seismic reflection profiles from the Glomar Challenger and Argo show thin sediment cover over low abyssal hills along the $140^{\circ} \mathrm{W}$ section from north of the Mendocino Fracture Zone until the thicker sediment on the shallower block south of the Clarion Fracture Zone is reached. In between there are two locations where anomalously thick sediments occur. One location is in association with the Clarion Fracture Zone (Figure 5) where an isolated hill north of the main topographic development of the zone is bordered by a thicker sediment section. The second location is the vicinity of Sites 40 and 41 . Here, two similar isolated large hills or ridges occur with thicker sediment surrounding them (Figures 6 and 7). These hills or ridges are only about 75 kilometers apart. Site 41 lies 15 kilometers northwest of Site 40-beyond the margin of the thicker sediment and at a water depth 150 meters greater than at Site 40 -approximately between the two large hills or ridges. Thus, the only other occurrence besides the Site 40 area of large isolated hills or ridges bordered by thicker sediment is near a fracture zone.

The thickness of the sediment at Site 40 is uncertain. The strong, smooth reflector at 0.21 second depth is chert. The Site Report (Chapter 10, this volume) shows the on-site seismic profile from which it was concluded that at least another 0.21 second of sediment containing weak reflectors is present below the chert. The sediment thickness is not restricted to the acoustically transparent material of Figures 6 and 7, but is at least twice that. The other localities in this general region in which relatively thick sediment fills have been recorded are certain crossings of fracture zones, such as that of the Clarion by Glomar Challenger between Sites 42 and 43 .

The sediment sections at Site 41 cannot be considered merely a condensed section of the time represented at Site 40 . Site 40 passes from "red" clay at the surface into Upper Eocene radiolarian ooze, successively underlain by Middle and then Lower Eocene radiolarian ooze and chert with an unknown thickness of sediment below the chert, possibly extending back into the Paleocene. The section at Site 41 consists of "red" clay at the surface with Upper Miocene or younger radiolarians underlain by Upper Eocene "red" clay, then Upper Eocene radiolarian ooze, and, finally, Middle Eocene radiolarian ooze immediately overlying the basalt. Considering the possible topography of the underlying basalt at the time of the deposition of the older sediment and assuming no subsequent major amount of relative vertical motion, the basalt at Site 41 would have stood some 250 meters above the basalt at Site 40 . The older sediment at Site 40 could have collected in troughs or basins, and these are commonly associated with fracture zones.

This assumed topography on the basalt is not too different from the double ridge topography of the sea floor described by Menard (1964) for the western part of the Murray Fracture Zone. The hill near Site 40 appears possibly to be an east-west ridge (Appendix III); it does not have the north-south trend of the smaller adjacent abyssal hills. Were the troughs of the Murray to be filled with sediment, a development analogous but not identical to the Site 40 area would appear. This explanation must assume that the older pelagic sediment is preserved in the troughs, but is not preserved outside the trough. Perhaps by Middle Eocene time, sediment was beginning to accumulate on the slopes of the troughs, as at Site 41 , while the troughs were being filled.

According to this explanation, the magnetic anomalies at these sites would be representative of a fracture zone, and therefore not correlatable with the age-dating anomalies of the blocks between fracture zones. This explanation is certainly not the only possible one, but it does conform with the observations made here.

\section{Conclusion}

The valid sites for comparison of the ages determined by the two methods appear to be Sites 32,38 and 39 , where the sediment is 6 or 8 million years younger than the magnetic anomaly age. This relation suggests that the dates for the various magnetic anomalies of Eocene and Paleocene age might be decreased by 6 million years for a better fit with the paleontological ages in this region. At Site 36 the magnetic anomaly ages near the top of the Miocene may require some revision, which, for at least one of the anomalies, would increase their age. At Site 34 the data are inconclusive, and at Site 41 a fracture zone may exist. If a fracture zone is not present, it is interesting to note that the age of the basal sediment at Site 41 correlates with that of the magnetic anomaly at that longitude north of the Molokai Fracture Zone. If such an age 


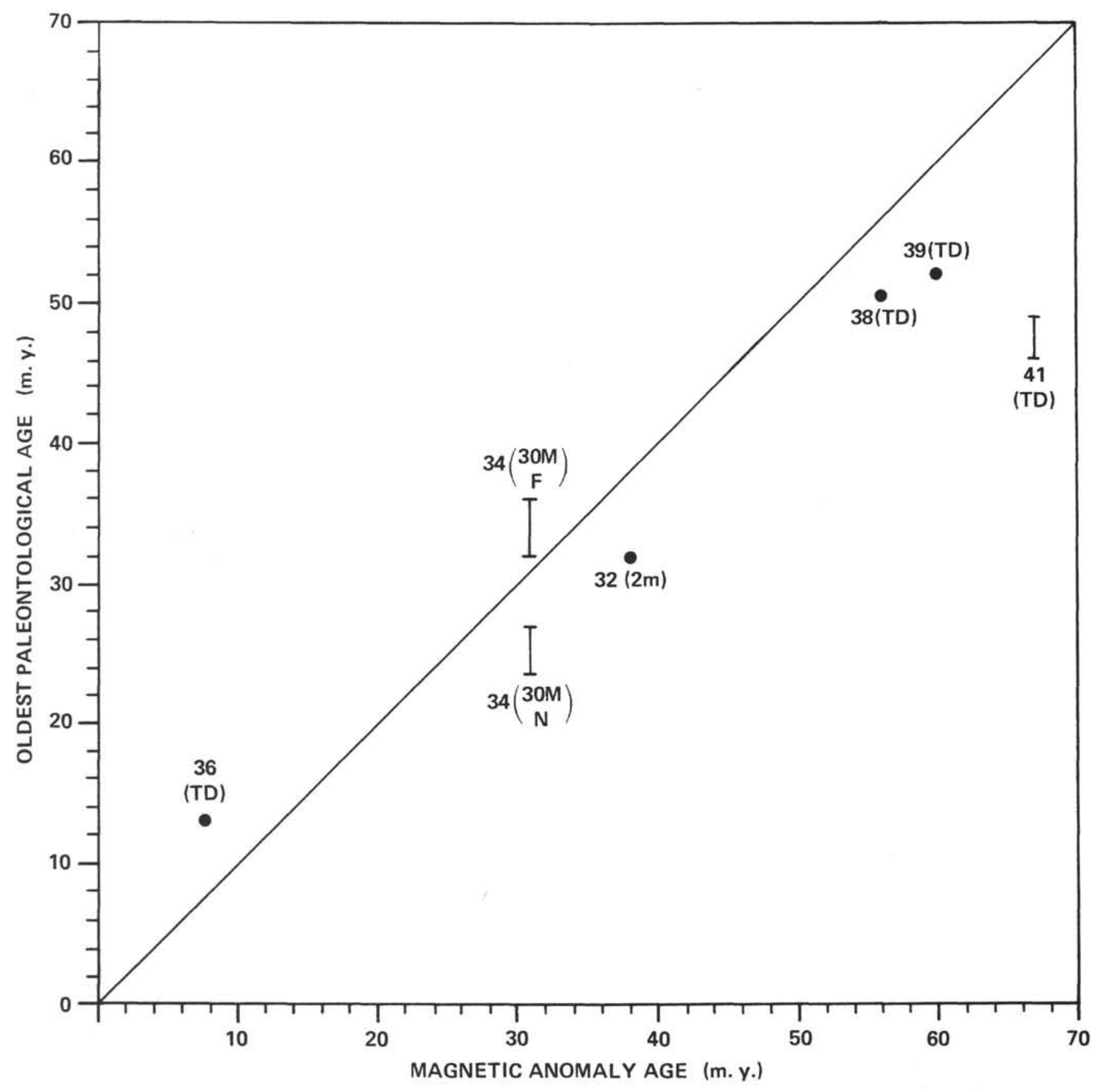

Figure 4. Comparison of oldest paleontological age of the sediment and magnetic anomaly age inferred for underlying basalt. (Underlined site numbers indicate sites where basalt may be intrusive. Numbers in parentheses show distance in meters above the basalt of sediment sample upon which paleontological age is based. TD signifies that deepest sediment sample was essentially overlying basalt. $F$ and $N$ represent foraminifera and calcareous nannoplankton ages in cases where significant differences in oldest ages occur.) 


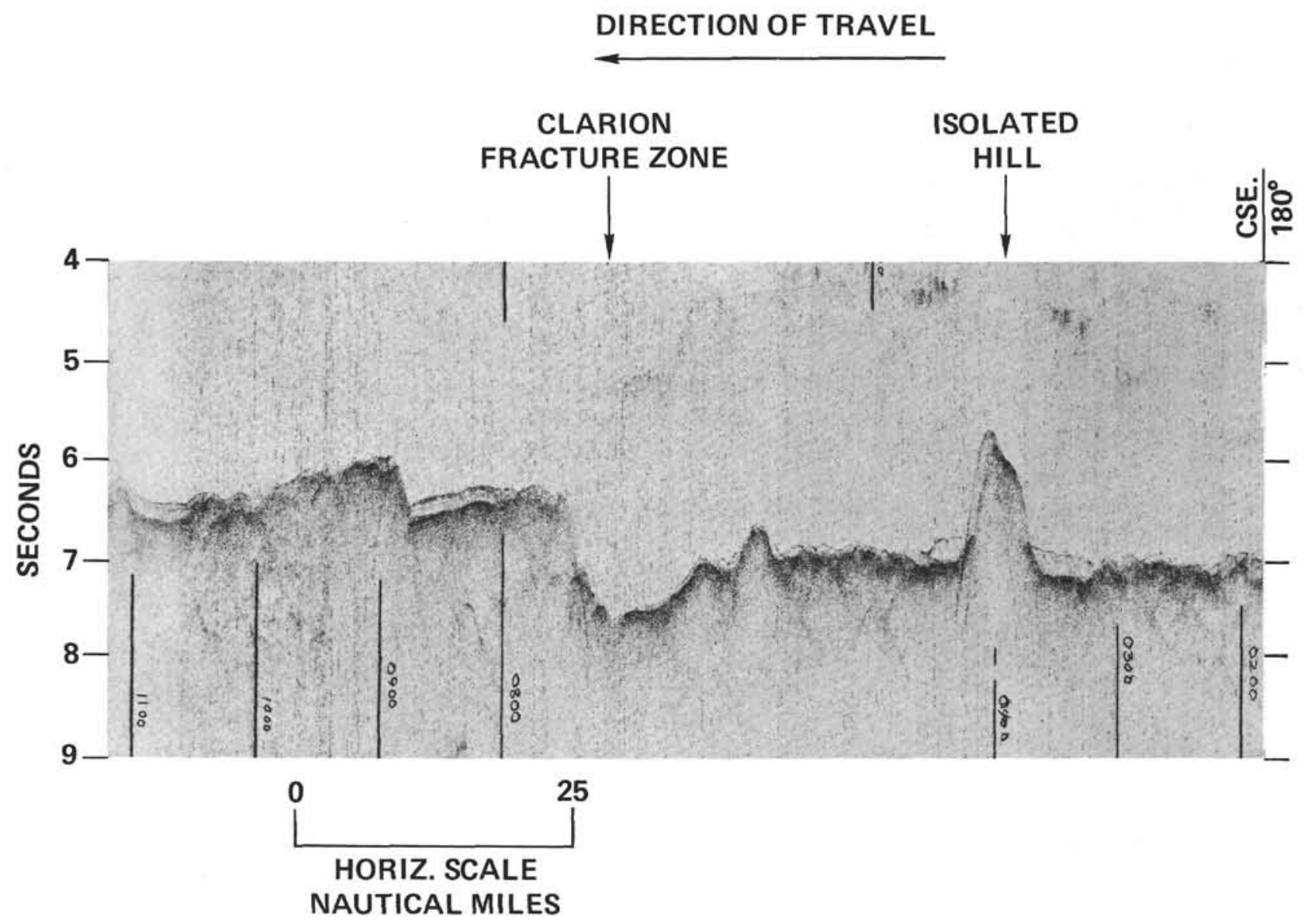

Figure 5. Seismic reflection profile from Argo across Clarion Fracture Zone (0700 on record) between Sites 41 and 42. Isolated hill at 0400 north of the fracture zone is bordered by thick acoustically transparent sediment overlying a smooth basement reflector that is probably chert. Horizontal scale is 11.4 nautical miles between hour marks on record. Vertical scale is 10 secs, 2-way travel time. 


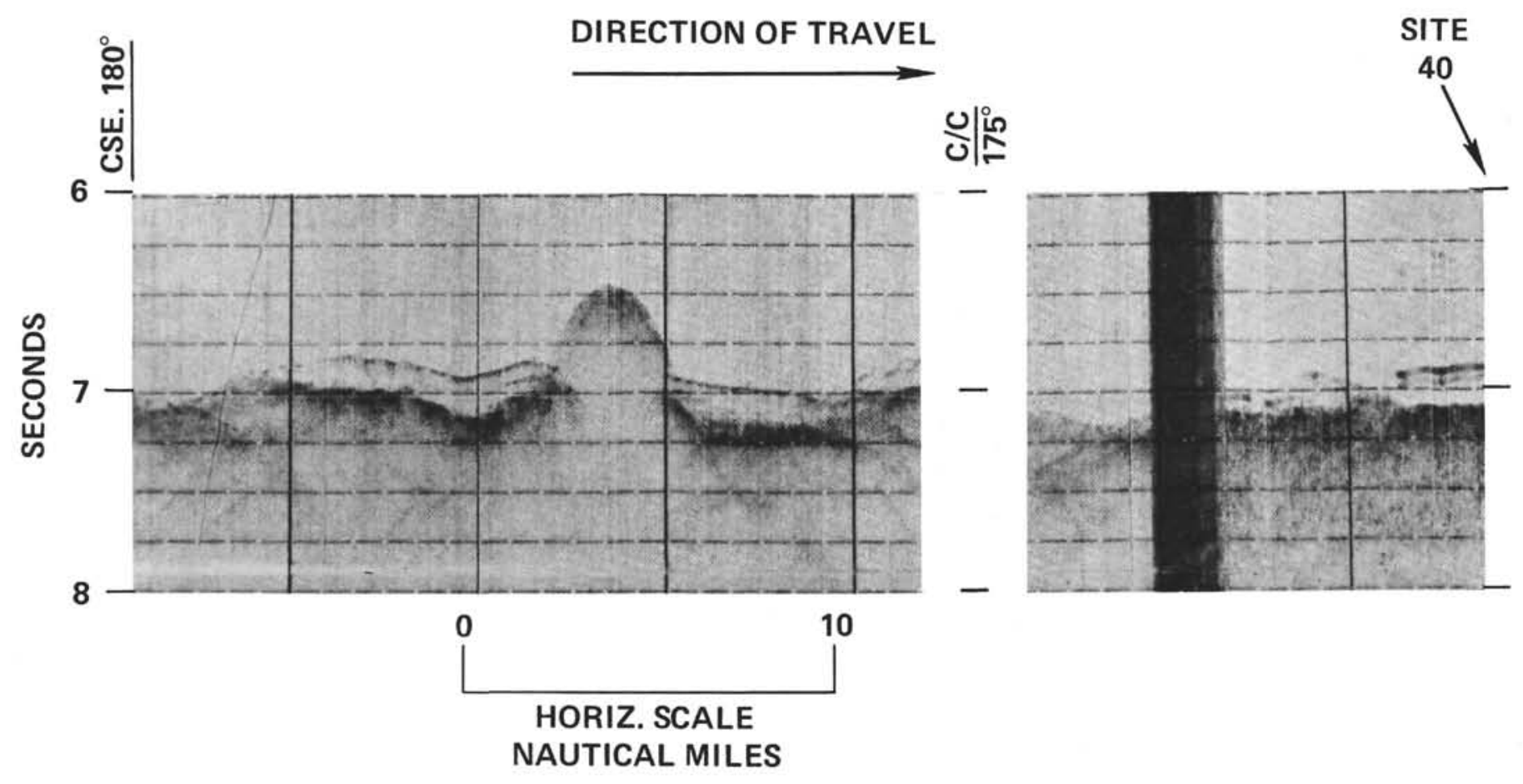

Figure 6. Seismic reflection profile from Glomar Challenger showing thicker sediment at right end of profile at Site 40 and similar occurrence around another large isolated hill 32 nautical miles north of Site 40 . The vertical scale is 5 secs, 2-way travel time. 


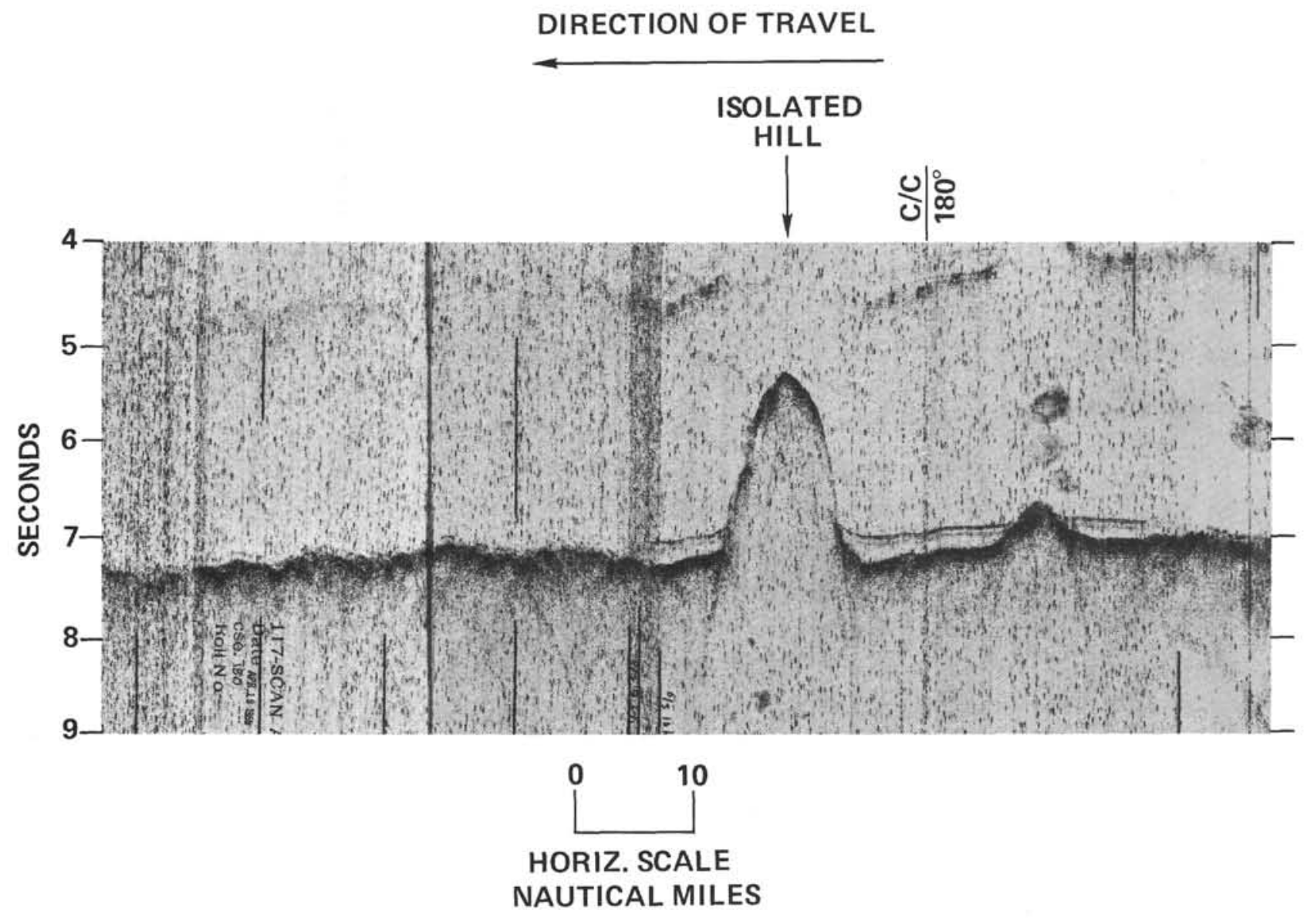

Figure 7. Seismic reflection profile from Argo showing thicker sediment, around isolated large hill or ridge, at Site 40. Width of base of large hill is about 8.5 nautical miles. Vertical scale: 10 secs, 2-way travel time. 
correlation exists, it would indicate no offset of the magnetic anomalies along this longitude of the Molokai Fracture Zone.

\section{OTHER ASPECTS OF LEG 5 DRILLING RESULTS}

There are several other regional aspects of the drilling results worthy of discussion. One is the restriction of the high barium content in the sediment to the area north of the Mendocino Fracture Zone. Another is the possibility that the amorphous iron-oxide facies apparently formed only at certain times during sea-floor spreading. A final suggestion towards the interpretation of these aspects may be appropriate in the light of existing knowledge. This suggestion would be that the fracture zones divide the ocean crust into distinctive blocks. Often there is considerable difference in seafloor elevation between adjoining blocks. Each block between fracture zones might well be considered a separate depositional province with a sedimentary history that may have very little that is correlatable with that of the section on the adjoining block. Such a distinction can apply to pelagic sediments as well as to terrigenous ones, although sediments dispersed by bottom-seeking currents would be more obviously affected. Even within the region encompassing one block, there may be prominent abyssal ridges subdividing it into individual sedimentary basins. This situation is exemplified by Sites 35 and 36 .

Another aspect which is of particular interest to West Coast geologists is how the sediments in the nearshore Leg 5 holes compare with those found at the present day onshore in California. From the discussions of Chapter 30, it is clear that the environmental factors affecting Sites 32 through 36 differ from those encountered in sedimentary basins which are now onshore.

An obvious distinction is the permanence of extreme water depths throughout the history of deposition at Sites 32 through 36 versus the oscillating depths accompanying sedimentation at onshore sites. This results in continuous deep-water marine facies in the former region, which contrasts with the deep-marine, shallow-marine and nonmarine facies in the latter region. In onshore West Coast stratigraphic sections unconformities are common, but they are rare offshore. Nevertheless, they are not precluded, as witnessed by the time-gaps found at Sites 32 and 36. It is only possible to speculate as to their cause in an oceanic environment.

At Site 32, sedimentary bypass and/or erosion may be responsible. Characterizing this region is a series of progressively deeper-in an offshore direction-stairstep-like basins, largely filled with turbidites. It is conceivable that as one basin fills, an abyssal gap leading to an adjoining basin siphons off subsequent turbidite flows, resulting in a depositional gap. Such conditions occur in the California Borderland and in other basins, particularly in the North Atlantic.

Near Site 36, accelerated bottom current flow resulting from prominent topographic changes on the sea floor may be responsible for unconformities (see Chapter 30).

With the proximity of the continental margin to Holes 32 through 36 and its remoteness from onshore areas, one naturally cannot relate the stratigraphic units found in the two regions. However, the two regions do have a certain degree of similarity in lithologic aspect, particularly with respect to the green to gray-green terrigenous muds and sands. Admittedly, at Sites 32, 33 and 34 the sand content is much less than that encountered in most California Cenozoic deep-water deposits. This can be explained by the location of these sites on the extreme distal portion of the Delgada Fan. Presumably the sand content in the sediments increases in amount and time-span in a shoreward direction. The Argo presite survey (see Chapter 30, Figure 7) gives evidence of this.

Most lithologically comparable to some of the deepwater sediments in typical California basins is the section at Site 35. In this case turbidite sands are liberally interspersed with silty muds; and, their rate of sedimentation $(560 \mathrm{~m} / \mathrm{m} . \mathrm{y}$.) is comparable to that accompanying deposition in onshore basins.

The depositional rates of the late Cenozoic time-rock units at Sites 32, 33, 34 and 36 range from 10 to 38 $\mathrm{m} / \mathrm{m} . \mathrm{y}$., and are generally lower than those encountered in comparable California intervals.

Quite distinctive in lithologic aspect are the pelagic "red" clays present in the bottoms of Holes 32 and 36. Counterparts of this sediment type are absent from onshore stratigraphic sections.

The biogenous constituents of Sites 32 through 36 are more nearly akin in their manner of occurrence to onshore strata than are the detrital components. Displaced and reworked microfossils are common to both areas. In onshore strata their presence is commonly ascribed to turbidity current transport. At the offshore sites, nepheloid-layer transport may be as much of a factor in their transport as turbidity currents.

Even more impressive is the development of the silica fossil-rich sediments at Sites 32, 33 and 34. Their composition and time-span closely parallels that of the Lower Sisquoc-Monterey Formations in southern California. Such a widespread occurrence is not entirely unexpected, due to the biogenous productivity of 
shallow waters above the thermocline. These deposits are not dependent on the vagaries of bottom current motion to the same degree as are clastic grains. All that is required for their generation is a high, replenishable nutrient content in surface waters. This condition apparently existed over a broad area, part of which is currently onshore, during much of Middle Miocene to earliest Pliocene time.

There is a marked difference in the degree of structural deformation experienced by the sediments at Sites 32 through 36 relative to that experienced by most California sediments. All the California basins experience strong folding, much downwarping, extensive lateral offset, pronounced block-faulting, or a combination of these modes of deformation.

The sediments by themselves give little evidence regarding deformation at the offshore sites. Much of the contorted bedding seen in the cores is believed to be due to the coring process. Only in the indurated Miocene sediments at the bottom of Hole 34 were reliable dips seen. These dips, which were of the order of 10 to 15 degrees, could have resulted from a deflected drill bit, although more likely they represent primary dip of sediments mantling the abyssal hills (see Chapter 30 , Figure 14). Most of the evidence for structural deformation comes from the Argo presite seismic profile.

At Site 36, no evidence of any structural deformation was seen. Site 32 records also show no deformed sediments. A few records (Appendix III) do indicate minor offset and folding of turbidite reflectors.

Somewhat more extensive structural deformation has taken place at Sites 33 and 34 . In these cases, the entire region between the Pioneer and Mendocino Fracture Zones has experienced compression. This has caused a broad north-south arching of the basement rocks and their overlying sediment cover (see Chapter 30, Figure 16, and Appendix III; also, note the curvature of the 4500 meter depth contour on Figure 13 in Chapter 30). A topographic contour map made of the Argo fathogram data shows some bowing in an eastwest direction, according to $\mathrm{O}$. E. Weser. Fairly recent small-scale faulting is present on some of the seismic records (Chapter 30, Figure 6).
The cause of this structural deformation is still speculative. Perhaps interaction between oceanic and continental plates in this part of the Pacific plays a role, although the region near Site 32 shows no such deformation. Possibly the slight change in direction of seafloor spreading north of the Mendocino Ridge is a factor. In this area the magnetic anomalies from Site 36 east (see Figure 4) change their orientation from being normal to the Mendocino Ridge to forming an acute angle. This could conceivably transmit a compressive stress to the region south of the Mendocino Ridge at a point east of the longitude of Site 36. This compression might even account for the sediment folding at the base of the Mendocino Escarpment which can be seen on some of the north-south seismic profiles crossing this feature (Chapter 30, Figure 8; Appendix III).

The flat-lying turbidites at Site 35, represented by the strong seismic reflectors seen on the seismic profiles, provide an accurate gauge of the structural deformation which has occurred. They show prominent blockfaulting and some folding in the Escanaba Trough (Chapter 30, Figures 9 and 10; Appendix III). Structural deformation is also evident in the area between Sites 35 and 36 (Chapter 30, Figure 11).

\section{REFERENCES}

Berggren, W. A., 1969. Cenozoic chronostratigraphy, planktonic foraminiferal zonation and the radiometric time scale. Nature. 224, 1072.

Maxwell et a.1, 1970. Initial Reports of the Deep Sea Drilling Project, Volume III. Washington (U. S. Government Printing Office).

Menard, H. W., 1964. Marine Geology of the Pacific. New York (McGraw-Hill).

Pitman, III, W. C. and Heirtzler, J. R., 1966. Magnetic anomalies over the Pacific-Antarctic Ridge. Science. $154,1164$.

Raff, A. D. and Mason, R. G., 1961. A magnetic survey off the west coast of North America, $40^{\circ} \mathrm{N}$ lat. to $52^{\circ} \mathrm{N}$ lat. Bull. Geol. Soc. Am. 72, 1267.

Vine, F. J., 1966. Spreading of the ocean floor; new evidence. Science. 154, 1405. 